\title{
Biochemical acromegaly in patients with prolactinoma during treatment with dopaminergic agonists
}

\author{
Acromegalia bioquímica em pacientes com prolactinoma \\ em tratamento com agonistas dopaminérgicos
}

Pedro W. Rosário ${ }^{1,2}$, Saulo Purisch²

1 Laboratório ANALYS, Belo Horizonte, MG, Brazil

${ }^{2}$ Departamento de Neuroendocrinologia, Serviço de Endocrinologia, Santa Casa de Belo Horizonte, MG, Brazil

\section{Correspondence to: Pedro W. Rosário Programa de Pós-graduação, Santa Casa de Belo Horizonte Av. Francisco Sales, $1111,9^{\circ} \mathrm{D}$ 30150-221 - Belo Horizonte MG, Brazil pedrorosario@globo.com}

Received on Dec/18/2009 Accepted on May/11/2010

\begin{abstract}
Objective: To evaluate the frequency of subclinical acromegaly (in the absence of clinical phenotype but biochemically uncontrolled) in patients with prolactinoma during treatment with dopaminergic agonists. Subjects and methods: One hundred twenty one patients without a phenotype suggestive of acromegaly were studied. Results: Initially, the laboratory diagnosis of acromegaly was unequivocal (elevated IGF-1 for gender and age with nadir GH $>1 \mu \mathrm{g} / \mathrm{L}$ ) in two patients, and likely (elevated IGF-1 with nadir GH $>$ cut-off but $<1 \mu \mathrm{g} / \mathrm{L}$ ) in another patient. In two other patients, this diagnosis was possible (normal IGF-1 with nadir GH $>1 \mu \mathrm{g} / \mathrm{L}$ ). Repetition of the tests 6 months after withdrawal of the dopaminergic agonist confirmed the diagnosis of subclinical acromegaly (elevated IGF-1 for gender and age with nadir GH $>1 \mu \mathrm{g} / \mathrm{L}$ ) in these 5 patients. False-positive results were excluded in all cases. Conclusion: In patients with prolactinomas, acromegaly should be investigated not only in cases with a clinical phenotype. Arq Bras Endocrinol Metab. 2010;54(6):546-9
\end{abstract}

Keywords

Acromegaly; prolactinoma; growth hormone; IGF-1

\section{RESUMO}

Objetivo: Avaliar a frequência de acromegalia subclínica (na ausência de fenótipo clínico, mas bioquimicamente não controlada) em pacientes com prolactinoma em tratamento com agonistas dopaminérgicos. Sujeitos e métodos: Cento e vinte e um pacientes sem fenótipo de acromegalia foram estudados. Resultados: Inicialmente, o diagnóstico laboratorial de acromegalia foi inequívoco (IGF-1 elevado para sexo e idade com nadir do $\mathrm{GH}>1 \mu \mathrm{g} / \mathrm{L}$ ) em dois pacientes, e provável (IGF-1 elevado com nadir do GH > valor de corte ensaio-específico mas $<1 \mu \mathrm{g} / \mathrm{L}$ ) em outro paciente. Em outros dois, esse diagnóstico foi possível (IGF-1 normal com nadir do GH $>1 \mu \mathrm{g} / \mathrm{L})$. A repetição dos testes seis meses após a suspensão dos agonistas dopaminérgicos confirmou o diagnóstico de acromegalia subclínica (IGF-1 elevado para sexo e idade com nadir do $\mathrm{GH}>1 \mu \mathrm{g} / \mathrm{L}$ ) em cinco desses pacientes. Os resultados falso-positivos foram excluídos em todos os casos. Conclusão: Em pacientes com prolactinomas, a acromegalia deveria ser investigada não apenas nos casos com fenótipo clínico. Arq Bras Endocrinol Metab. 2010;54(6):546-9

Descritores

Acromegalia; prolactinoma; hormônio de crescimento; IGF-1

\section{INTRODUCTION}

$\mathrm{C}$ o-secretion of prolactin (PRL) and growth hormone (GH) by pituitary adenomas and hyperprolactinemia secondary to a reduction of dopaminergic tonus in $\mathrm{GH}$ producing macroadenomas are not rare $(1,2)$. Concomi- tant hypersecretion of $\mathrm{GH}$ in prolactinomas cannot be suspected because of the predominance of clinical manifestations of hyperprolactinemia (3), and there is currently no recommendation for the routine investigation of acromegaly in patients with prolactinomas (1). 
When patients with prolactinoma and co-secretion of $\mathrm{GH}$ are treated with dopaminergic agonists, normalization of PRL accompanied by the remission of hyperprolactinemia symptoms is the rule (1). Difficulties lie in that the same response is not observed for GH and insulin-like growth factor 1 (IGF-1) in a marked proportion of patients (4-6), with persistence of hypersecretion of these hormones. Since biochemically uncontrolled acromegaly, even when asymptomatic, is associated with higher morbidity and mortality (2), the identification of these cases is important. This study evaluated the frequency of biochemically uncontrolled acromegaly in patients with prolactinoma during treatment with dopaminergic agonists. The objective was to identify subjects without clinical phenotype and patients for whom there is currently no recommendation for routine investigation of acromegaly ( 1 ).

\section{SUBJECTS AND METHODS}

This was a cross-sectional study. A total of 121 subjects with a diagnosis of prolactinoma, who were already being treated with dopaminergic agonists, were studied. Inclusion criteria were: a) hyperprolactinemia (> $100 \mathrm{ng} / \mathrm{mL}$ for macroprolactinoma and $>50 \mathrm{ng} / \mathrm{mL}$ for microprolactinoma), excluding medications that can cause hyperprolactinemia, primary hypothyroidism and macroprolactinemia; b) pituitary adenoma upon imaging (magnetic resonance or computed tomography) (> $10 \mathrm{~mm}$ for macroprolactinoma and $\leq 10 \mathrm{~mm}$ for microprolactinoma); c) normalization of PRL levels accompanied by a $>50 \%$ reduction in tumor size after dopaminergic agonist treatment.

Exclusion criteria were the presence of a phenotype suggestive of acromegaly (the objective was to identify clinically not suspected cases); moderate elevation of PRL (< $100 \mathrm{ng} / \mathrm{mL}$ ) associated with a non-cystic macroadenoma; or no change or only a small reduction in macroadenoma despite normalization of PRL after some months of treatment with dopaminergic agonists. The last two conditions lead to the diagnosis of nonprolactinoma macroadenoma ( 1 ) for which investigation of GH hypersecretion is already recommended (7-9) (the objective was to identify cases for which there is currently no recommendation for the investigation of acromegaly). Acral enlargement including thickness of soft tissue of hands and feet, prognathism, jaw malocclusion, hypertrophy of frontal bones were considered for the definition of the phenotype suggestive of acromegaly $(2,10)$.
The study was approved by the local Ethics Committee.

Serum IGF-1 and basal GH were assayed. Patients presenting elevated IGF- 1 levels for gender and age or basal GH $>0.25 \mu \mathrm{g} / \mathrm{L}$ for men or $>0.7 \mu \mathrm{g} / \mathrm{L}$ for women (11) were reevaluated after 1 week by the measurement of $\mathrm{GH}$ during the oral glucose tolerance test (OGTT) and a new measurement of IGF-1. Nadir GH in the OGTT $>0.25 \mu \mathrm{g} / \mathrm{L}$ for men or $>0.7 \mu \mathrm{g} / \mathrm{L}$ for women (11) or persistently elevated IGF-1, in the absence of any other apparent cause of these findings, were considered to be abnormal. The tests were repeated 6 months after withdrawal of the dopaminergic agonist in patients with initially altered nadir GH or IGF-1 to guarantee the persistence of laboratory anomalies and to rule out the effect of drug treatment in cases in which nadir GH and IGF-1 were discordant.

PRL was measured using the ICMA Immulite kit (Diagnostic Products Corporation, Los Angeles, CA), with a reference value of $2.5-17 \mathrm{ng} / \mathrm{mL}$ for men and 2.5-20 ng/mL for women. IGF-1 was measured by the IRMA DSL-5600 Active assay (Diagnostic Systems Laboratories, Inc., Webster, TX) using standards calibrated to the 2nd WHO IS $87 / 518$ and age- and gender-specific reference values. GH was assayed using the ICMA Immulite kit (Diagnostic Products Corporation) using standards calibrated to the 2 nd WHO IS 98/574 and a previously established cut-off (11).

OGTT: Serum samples were obtained before and $30,60,90$ and 120 minutes after oral administration of $75 \mathrm{~g}$ glucose. The samples were collected in the morning after an approximately 10-h fast, with the subject resting for $20 \mathrm{~min}$ before and during the test.

\section{Statistical analysis}

Sample size was calculated using the following formula:

$$
n=\frac{Z_{c}^{2} \pi(1-\pi)}{\varepsilon_{p}^{2}}
$$

where $\mathrm{n}=$ sample size; $\mathrm{Z}_{\mathrm{c}}($ reliability $)=1.96 ; \pi($ estimated frequency $)=4 \%(12) ; \epsilon_{p}($ error estimate $)=3.5 \%$.

\section{RESULTS}

The characteristics of the population studied and data regarding the 10 patients with initially altered nadir GH and/or IGF- 1 are shown in tables 1 and 2, respectively. 
In every case, situations associated with false-positive GH and IGF-1 results were excluded (pregnancy, thyroid dysfunction, puberty, malnutrition, diabetes, kidney or liver disease, and drugs including anovulatory agents, estrogens or corticosteroids). After this step, laboratory anomalies were interpreted as follows (1,7-9). The diagnosis of biochemically active acromegaly was unequivocal (elevated IGF-1 for gender and age with nadir $\mathrm{GH}>\mathrm{l} \mu \mathrm{g} / \mathrm{L}$ ) in two patients (patients $\mathrm{l}$ and 10 in table 2). This diagnosis was likely (elevated IGF$\mathrm{l}$ with nadir $\mathrm{GH}>$ cut-off but $<\mathrm{l} \mu \mathrm{g} / \mathrm{L})$ in another patient (patient 4). In two other patients (patients 6

Table 1. Characteristics of the population studied

\begin{tabular}{|c|c|c|}
\hline Characteristic & $\begin{array}{l}\text { Microprolactinoma } \\
\quad(\mathrm{n}=\mathbf{8 0})\end{array}$ & $\begin{array}{l}\text { Macroprolactinoma } \\
(n=41)\end{array}$ \\
\hline Gender & 70 women, 10 men & 27 women, 14 men \\
\hline $\begin{array}{l}\text { Age at assessment } \\
\text { [range (median)] }\end{array}$ & 20-66 (35 years) & 21-73 (42 years) \\
\hline Symptomatic* (at diagnosis) & $76(95 \%)$ & $41(100 \%)$ \\
\hline $\begin{array}{l}\text { Prolactin levels at diagnosis } \\
\text { [range (median)] }\end{array}$ & 52-382 (160 g/L) & $156-7.200(910 \mu \mathrm{g} / \mathrm{L})$ \\
\hline Tumor size [range (median)] & $3-10(6 \mathrm{~mm})$ & $11-41(18 \mathrm{~mm})$ \\
\hline Hypopituitarism & 0 & $13(31.7 \%)$ \\
\hline $\begin{array}{l}\text { Duration of dopaminergic } \\
\text { agonists treatment [range } \\
\text { (median)] }\end{array}$ & 12-60 (32 months) & 12-58 (30 months) \\
\hline Use of bromocriptine & $38(47.5 \%)$ & $12(29.2 \%)$ \\
\hline $\begin{array}{l}\text { Daily bromocriptine dose } \\
\text { [range (median)] }\end{array}$ & $1.25-10(5 \mathrm{mg})$ & 5-15 (7.5 mg) \\
\hline Use of cabergoline & $42(52.5 \%)$ & $29(70.3 \%)$ \\
\hline $\begin{array}{l}\text { Weekly cabergoline dose } \\
\text { [range (median)] }\end{array}$ & $0.5-2(0.5 \mathrm{mg})$ & $0.5-3(1 \mathrm{mg})$ \\
\hline
\end{tabular}

* Women: oligo- or amenorrheic, chronic anovulation, galactorrhea; men: hypogonadism. and 9), this diagnosis was possible (normal IGF- 1 with nadir $\mathrm{GH}>1 \mu \mathrm{g} / \mathrm{L}$ ). In three patients (patients 2, 5 and 7 in table 2) with discretely elevated IGF-1, adequate suppression of GH in the OGTT ruled out active acromegaly. Finally, two cases (patients 3 and 8) with normal IGF-1 and discretely elevated nadir GH were classified as not having active acromegaly. Repetition of the tests 6 months after withdrawal of the dopaminergic agonist confirmed the diagnosis in patients 1,4 and 10 and resulted in an unequivocal diagnosis in patients 6 and 9.

Patients 6 and 10 were submitted to transsphenoidal surgery and immunohistochemistry confirmed the positivity for GH and PRL. In patients 1 and 4, octreotide LAR was added to the initial treatment (dopaminergic agonist), and on the last assessment IGF-1 was 1.1 and 1.2 time the upper limit of the reference range, respectively. Patient 9 had still not started treatment with octreotide LAR and was only using a dopaminergic agonist.

\section{DISCUSSION}

GH hypersecretion might be present in hyperprolactinemia associated with pituitary adenoma due to cosecretion of these hormones or a reduction of dopaminergic tonus caused by macrosomatotropinoma $(1,2)$. Investigation for acromegaly should be performed in the presence of a suggestive phenotype or of an adenoma unlikely to be a prolactinoma (7-9), which is suspected in the presence of moderate hyperprolactinemia associated with non-cystic macroadenoma or in the absence of marked tumor reduction after some months of

Table 2. Characteristics and results of the patients with initially altered nadir GH and/or IGF-1

\begin{tabular}{|c|c|c|c|c|c|c|c|}
\hline \multirow{2}{*}{ Patient } & \multirow{2}{*}{ Gender } & \multirow{2}{*}{ Age (years) } & \multirow{2}{*}{ Adenoma size } & \multicolumn{2}{|c|}{ Nadir GH $(\mu \mathrm{g} / \mathrm{L})^{*}$} & \multicolumn{2}{|c|}{ IGF-1 (patient)/ULN } \\
\hline & & & & Initial & 6 months off DA & Initial & 6 months off DA \\
\hline 1 & Female & 29 & Micro (8 mm) & 1.5 & 2.1 & 1.6 & 1.85 \\
\hline 2 & Male & 50 & Micro (5 mm) & 0.15 & 0.14 & 1.1 & 1 \\
\hline 3 & Female & 30 & Micro (6 mm) & 0.84 & 0.65 & 0.75 & 0.7 \\
\hline 4 & Male & 54 & Macro (15 mm) & 0.9 & 1.5 & 1.75 & 2 \\
\hline 5 & Female & 32 & Micro (7 mm) & 0.4 & 0.36 & 1.1 & 0.9 \\
\hline 6 & Female & 45 & Macro (22 mm) & 1.6 & 2.2 & 0.9 & 1.5 \\
\hline 7 & Female & 44 & Macro (12 mm) & 0.35 & 0.3 & 1.2 & 1 \\
\hline 8 & Female & 35 & Macro (20 mm) & 0.9 & 0.72 & 0.6 & 0.65 \\
\hline 9 & Female & 36 & Macro (17 mm) & 2 & 2.5 & 0.95 & 1.4 \\
\hline 10 & Female & 41 & Macro (20 mm) & 1.8 & 2.5 & 1.5 & 1.8 \\
\hline
\end{tabular}

DA: dopaminergic agonist; ULN: upper limit of the reference value for gender and age.

* Gender- and assay-specific cut-off: > $0.25 \mu \mathrm{g} / \mathrm{L}$ for men and $>0.7 \mu \mathrm{g} / \mathrm{L}$ for women (11). 
dopaminergic agonist treatment and normalization of PRL (1). Investigation of acromegaly is not recommended in the remaining cases ( 1 ).

Following current recommendations for the treatment of prolactinomas (1), there is a high likelihood that underlying GH hypersecretion will not be controlled. Surgery is indicated in exceptional cases. Patients with microprolactinomas cannot be treated or only receive sex hormones. Dopaminergic agonists, the main therapeutic modality for prolactinomas, do not normalize GH or IGF-1 levels in a marked proportion of cases, even in the presence of PRL co-secretion (4-6).

Since biochemically uncontrolled acromegaly is associated with higher morbidity and mortality $(2,13)$, the identification of these patients is important. If no intervention is indicated, specific follow-up is recommended for cases of only discretely altered GH or IGF-l in order to detect the progression of laboratory anomalies, and greater attention should be paid to clinical signs of excess GH/IGF-1. More importantly, treatment might be modified in the case of patients with altered GH and IGF-1, with the indication of surgery or treatment with somatostatin analogs even in the absence of clinical activity $(2,13)$. Even in the case of patients who achieve remission (normal GH/ IGF-1) with treatment with dopaminergics agonists, co-morbidities related to excess GH/IGF-1 may also be present, and their detection and specific management are important (14).

Analysis of our patients with prolactinoma during successful treatment with dopaminergic agonists showed a frequency of biochemically uncontrolled acromegaly of $4.1 \%$. This rate is relevant since it specifically refers to patients without a clinical phenotype. This was a cross-sectional study and we are unable to determine when biochemical GH/IGF-1 hypersecretion occurred. If we assume that all patients presented inappropriate $\mathrm{GH}$ secretion since diagnosis, the prevalence might be higher than that observed since altered GH and IGF-1 could have been present before treatment with dopaminergic agonists in patients presenting normal parameters on this assessment. Since Andersen and cols. (12) showed that GH hypersecretion not detected at diagnosis of the prolactinoma can arise subsequently, it is possible that the onset of hypersecretion occurred after the diagnosis in some of the patients and the fre- quency found in this cross-sectional study may still increase over time.

In summary, we conclude that among patients with prolactinomas, acromegaly should be investigated not only in cases with clinical phenotype. Since biochemically uncontrolled acromegaly is associated with higher morbidity and mortality, the identification of these patients is important.

Acknowledgments and disclosure: This study was supported by grants from Novartis Biociências.

\section{REFERENCES}

1. Casanueva FF, Molitch ME, Schlechte JA, Abs R, Bonert V, Bronstein MD, et al. Guidelines of the Pituitary Society for the diagnosis and management of prolactinomas. Clin Endocrinol (Oxf). 2006;65:265-73.

2. Melmed S. Medical progress: acromegaly. $\mathrm{N}$ Engl J Med. 2006;355:2558-73.

3. Sakharova AA, Dimaraki EV, Chandler WF, Barkan AL. Clinically silent somatotropinomas may be biochemically active. J Clin Endocrinol Metab. 2005;90:2117-21.

4. Jaffe CA, Barkan AL. Treatment of acromegaly with dopamine agonists. Endocrinol Metab Clin N Am. 1992;121:713-35.

5. Abs R, Verhelst J, Maiter D, Van Acker K, Nobels F, Coolens JL, et al. Cabergoline in the treatment of acromegaly: a study in 64 patients. J Clin Endocrinol Metab. 1998;83:374-8.

6. Sherlock M, Fernandez-Rodriguez E, Aragon AA, Reulen RC, Ayuk J, Clayton RN, et al. Medical therapy in patients with acromegaly; predictors of response and comparison of efficacy of dopamine agonists and somatostatin analogues. J Clin Endocrinol Metab. 2009;94:1255-63.

7. Molitch ME. Nonfunctioning pituitary tumors and pituitary incidentalomas. Endocrinol Metab Clin N Am. 2008;37:151-71.

8. Mavrakis A, Tritos N. Diagnostic and therapeutic approach to pituitary incidentalomas. Endocr Pract. 2004;10:438-44.

9. Daly AF, Burlacu MC, Livadariu E, Beckers A. The epidemiology and management of pituitary incidentalomas. Horm Res. 2007;68(Suppl 5):195-8.

10. Ezzat S, Forster MJ, Berchtold P, Redelmeier DA, Boerlin V, Harris AG. Acromegaly. Clinical and biochemical features in 500 patients. Medicine (Baltimore). 1994;73:233-40.

11. Rosario PW, Furtado MS. Growth hormone after oral glucose overload: revision of reference values in normal subjects. Arq Bras Endocrinol Metab. 2008;52:1139-44.

12. Andersen M, Hagen C, Frystyk J, Schroeder HD, Hagen C. Development of acromegaly in patients with prolactinomas. Eur $\mathrm{J}$ Endocrinol. 2003;149:17-22.

13. Melmed S, Colao A, Barkan A, Molitch M, Grossman AB, Kleinberg D, et al.; Acromegaly Consensus Group. Guidelines for acromegaly management: an update. J Clin Endocrinol Metab. 2009;94:1509-17.

14. Colao A, Ferone D, Marzullo P, Lombardi G. Systemic complications of acromegaly: epidemiology, pathogenesis, and management. Endocr Rev. 2004;25:102-52. 